\title{
Program initiatives of public authorities in the field of hydrogenation of the economy in a global perspective, as of the end of 2020
}

In the years 2016-2020, there has been a significant acceleration in the development of technologies for the hydrogen energy use and their popularization in practice. The value of the global hydrogen market in 2018 was estimated at US $\$ 122$ billion, predicted that it will increase to US $\$ 155$ billion by the 2022. The appropriate policy framework has a major impact on the development of new technologies, in particular during research, prototype implementations and the initial phase of their commercialization. Of course, this also fully applies to hydrogen technologies, which was confirmed, i.a., in its study by The Hydrogen Council, a leading global organization in this field. The spearheading countries intensively involved in the development and dissemination of hydrogen technologies are primarily: Japan, China, South Korea, Germany, France, Great Britain, Scandinavian and Benelux countries, as well as Canada and the USA. A dozen more countries making up the leading group, such as: Italy, Spain, Portugal, Australia, New Zealand, Brazil, India and South Africa are making efforts to join the global hydrogen race and complete the leading group. The scale of the global development of hydrogen technologies is illustrated by the fact that at the end of 2019, vehicles with hydrogen fuel cells and the publicly accessible hydrogen refuelling stations serving them already operated in 18 countries. An effective use of the incurred expenditures undoubtedly requires the interested states to formulate an appropriate policy (strategy) for the hydrogenation of the economy, including, in addition to precisely defined long-term objectives, e.g. elements of support from public administration, assurance of: stable investment conditions and the necessary regulatory conditions. The article attempts to synthetically present the political framework, i.e. the function-

Received. 14 July 202 ing plans and programs as well as national strategies for the development of hydrogen technology and economy Accepted: 12 September 2021

Available online: 24 September 2021 in 19 countries.

Key words: greenhouse gases, hydrogen vehicles, emission measurement, directions of automotive development

This is an open access article under the CC BY license (http://creativecommons.org/licenses/BY/4.0/)

\section{Introduction}

In the years 2016-2020, there has been a significant acceleration in the development of technologies for the hydrogen energy use and their popularization in practice. The value of the global hydrogen market in 2018 was estimated at US $\$ 122$ billion, predicted that it will increase to US $\$ 155$ billion by the 2022 [1].

The appropriate policy framework has a major impact on the development of new technologies, in particular during research, prototype implementations and the initial phase of their commercialization. Of course, this also fully applies to hydrogen technologies, which was confirmed, i.a., in its study by The Hydrogen Council, a leading global organization in this field.

In the 2017 study, it clearly stated that the development of appropriate programs and strategies for the hydrogenation of the economy should be the starting point and the way to the dynamic development of hydrogen technologies, optimizing the costs of this development and achieving an adequate level of profitability as soon as possible [2].

The spearheading countries intensively involved in the development and dissemination of hydrogen technologies are primarily: Japan, China, South Korea, Germany, France, Great Britain, Scandinavian and Benelux countries, as well as Canada and the USA.

A dozen more countries making up the leading group, such as: Italy, Spain, Portugal, Australia, New Zealand, Brazil, India and South Africa are making efforts to join the global hydrogen race and complete the leading group. The scale of the global development of hydrogen technologies is illustrated by the fact that at the end of 2019, vehicles with hydrogen fuel cells and the publicly accessible hydrogen refuelling stations serving them already operated in 18 countries [3].

The article attempts to synthetically present the political framework, i.e. the functioning plans and programs as well as national strategies for the development of hydrogen technology and economy in 19 countries.

\section{National strategies for the development of hydrogen technology and economy in 19 countries}

\section{Australia}

Work on the hydrogen energy use was undertaken in Australia in the last years of the 20th century.

Australia is a specific country where, apart from numerous projects related to the development of hydrogen technologies, a lot is related to the production of hydrogen itself (out of 120 hydrogen projects carried out by the 2005, 55 were related to obtaining hydrogen from fossil fuels and in water electrolysis processes) [4]. This is due, on the one hand, to Australia's possession of raw materials and climate conditions, and on the other hand, to the relative proximity of the large hydrogen markets of Japan, China and South Korea.

Australia's hydrogen export potential was a precondition for undertaking work on a hydrogen economy in this country as early as the early 2000s. The export of the hydrogen produced is considered not only the most important stimulator of the development of the hydrogen economy in Australia, but also one of the basic levers of the assumed economic development of the country [5]. 
Transport in Australia has been adopted as the primary national area for the energy use of hydrogen, including also technological transport in mining plants or handling equipment [6].

The national roadmap for building a sustainable and effective hydrogen industry has defined the directions for the development of a clean, innovative, safe and competitive hydrogen industry prepared by the government administration, and at the same time established an expert group (Hydrogen Working Group) which was tasked with developing the National Hydrogen Strategy. The Australian Hydrogen Strategy, which includes 57 necessary measures, was published in 2019 [7].

Relevant strategies were also published by the largest Australian states, incl. South Australia [8] and Queensland [9].

The Australian central government alone allocated US $\$ 256$ million to the research, feasibility studies and demonstration projects in 2015-2019.

\section{Chile}

The first country on the South American continent to prepare a strategic document for the development of the hydrogen economy is Chile. The leading element in the national hydrogen strategy published in November 2020 is "green" hydrogen, with the production of which Chile intends to conquer world markets [10].

It is supported by the country's natural conditions, which provide potentially large amounts of cheap electricity from renewable sources (highly sunny desert areas in the north of the country and windy areas in the south of the country), which exceed the domestic demand 70 times. With the cheap electricity, the cost of producing hydrogen, oscillating around $0.8-1$ dollar $/ \mathrm{kg}$ of hydrogen, is among the lowest in the world.

Cheap sources of renewable energy and the "green" hydrogen produced, on the one hand, is to ensure Chile's emission neutrality by 2050 , on the other hand, by the 2030 , it is to make it one of the three leading exporters of green hydrogen. According to McKinsey \& Co's estimates, by the 2030 the Chilean production potential will reach 25 million tons of "green" hydrogen (5\% of global demand), for which the country will export 30 billion dollars annually, ensuring $50 \%$ of supplies of this energy carrier to Japan and South Korea, and $20 \%$ to China [11].

The use of "green" hydrogen energy in the country, which is to ensure a $20 \%$ share in reducing $\mathrm{CO}_{2}$ emissions, is to be concentrated in the gas industry and ecological refining of the mined copper ores.

The assumed development of the hydrogen sector will require investments of approximately USD 200 billion in the next 20 years, which will generate 100,000 new jobs. The Strategy assumes that by the 2025 the total capacity of electrolysers installed in the country will exceed $5 \mathrm{GW}$. The first Chilean green hydrogen plant to be built in Cabo Negro north of Punta Arenas, consisting of a 3.4 MW wind farm and a 1.25 MW electrolyser, will be commissioned in early 2022.

\section{China}

Chinese work on the use of hydrogen energy began in the mid-1950s in the space and military sector.
At the end of the 1980s, research into hydrogen technologies was also undertaken by the civilian sector, and mainly related to road transport. From the very beginning, these studies were carried out under centralized research programs, five-year economic and social development plans of the country as well as regulations and orders of public administration.

The first program with hydrogen propulsion technologies as a component - "National High Technology Research and Development Program" launched in 1987, operated until 2016 [12]. In 1997, the Basic Research Program was launched, which also ran until 2016. Since 2016, research and development work has been carried out under the National Key Research and Development Programs [13]. The directions of the conducted research result from the findings of the next five-year plans for China's socioeconomic development.

In the tenth plan for 2001-2005 the issues of hydrogen vehicles were included in the "Electric Vehicle" part, in the eleventh plan for the years 2006-2010 in the "Energy saving a new energy vehicle" part, and in the twelfth plan for 20112015 in the "Electric vehicle critical technology "and in the thirteenth plan for 2016-2020 in the part "Energy storage and distributed energy and new energy vehicles" [14].

In May 2015, the Chinese authorities published a tenyear program "Made in China 2025" to modernize ten priority industrial sectors, including the automotive sector, with particular emphasis on the production of vehicles with alternative drives, including hydrogen one [15].

In reference to the above, in 2016 the Strategic Advisory Committee for the technological roadmap for the development of energy-saving technologies and vehicles with alternative drives published, inter alia, "Roadmap for Hydrogen Technologies" [16]. The study assumes that by the 2020, 5,000 hydrogen powered vehicles will be used in China, served by 100 hydrogen refuelling stations, and in 2030 one million vehicles served by more than 1,000 stations.

The specifics of this report, as well as other research works, resulting from the Chinese economic model, is the precise setting of not only strategic objectives, but also dozens of specific goals regarding, for example, the parameters of hydrogen-powered vehicles and their components, and even individual components.

Hydrogenization of transport, as one of the 15 development directions, was also established in the "energy technological revolution and innovative action plan for 20162030" published in 2016 by the Development and Reform Committee and the National Energy Agency [17].

The development of hydrogenation in the road transport achieved by the first quarter of 2020: 72 refuelling stations and 6,564 vehicles (mainly low-capacity buses and lightduty trucks) - fulfilling the assumptions of the roadmap from 2016, is a derivative of the public administration's commitment, which spent on the development of the electric car sector over USD 58 billion, including USD 12 billion alone on the development of hydrogenation of transport in 2018 [18].

In recent years in China, the issue of the development of hydrogen technologies outside the transport sector, includ- 
ing in March 2019, the issue of the hydrogen energy use was included in the annual speech of the Chinese Prime Minister at the session of the 13th Chinese People's Assembly [19]. The issue of the hydrogen economy was also raised by Chinese President Xi Jinping in his speech on September 22, 2020 announcing China's intention to achieve carbon neutrality by the 2060 [19].

This does not change the fact that to date China does not have a national strategy for the hydrogenation of the economy. In June 2019, the Chinese Hydrogen Alliance (H2CN) established in 2018 by 18 different types of entities, supervised and supported primarily by the Chinese Ministry of Science and Technology, published its own version of the vision of the development of Chinese economy hydrogenation by 2050, which was not an official document [20].

The assumed vision envisages that by the 2050 the share of hydrogen in the national energy balance will increase from $2.7 \%$ in 2019 to $10 \%$, the turnover of the hydrogen market will increase from USD 43.5 billion to USD 1.7 trillion, the number of hydrogen refuelling stations will increase 72 to 10,000 , and the number of hydrogenpowered passenger cars will increase from several hundred to 5 million. In China, there will be more and more buses and trucks with fuel cells, and the number of hydrogen fuel cell installations will increase from 10,000 . up to 5.5 million [19].

\section{Denmark}

Denmark is one of the countries in which work on a national strategy for the development of hydrogen economy was initiated at the earliest. As early as 1998, work began on the development of an appropriate program "The Danish hydrogen energy program" [21].

In the Danish activities, the emphasis was placed, apart from the use of hydrogen as a carrier of electricity, on its use in transport. In 2008, the first version of the relevant sectoral program - "National R\&D and demostration strategy for FCH transport" was prepared [22]. Based on the above document, in 2014 the Danish transport hydrogenation program "National Implementation Plan (NIP) for hydrogen refuelling infrastructure in Denmark" was published. The program assumed significant financial reliefs both in relation to the costs of purchasing hydrogen vehicles (exemption from registration taxes amounting to $105 \%$ of the purchase price and $180 \%$ if their price exceeds 10.6 thousand euro), and also in relation to the costs of their operation (exemption from annual road tax) [23].

Exemption from the registration tax, amounting to approx. 30,000 EURO already makes the cost of purchasing a car equipped with hydrogen fuel cells competitive with respect to corresponding mid-range car with an internal combustion engine.

Hydrogen refuelling stations are co-financed up to $50 \%$ in both, the construction costs and the costs of subsequent operation. The above rules for promoting the development of hydrogenation in Danish transport are to apply according to the current regulations until 2025.

\section{Finland}

Work on the use of hydrogen energy began in Finland in the early 2000s. In 2007, a multi-annual (until 2013) hydro- gen program was launched, coordinated by the Finnish Agency for Technology and Innovation (Tekes) [24].

In 2013, the Finnish research centre VTT developed the first national roadmap for the development of hydrogenation in the road transport. The above-mentioned Research Centre also prepared a roadmap for the development of hydrogen technologies in Finland in 2020, at the request of Business Finland [25].

Apart from the advantages of hydrogen as an energy carrier, the paper describes the state of development of hydrogen technologies in the country, discusses the role and costs of production, including the costs of producing "green" hydrogen (the total capacity of wind farms installed in Finland already exceeds $2.3 \mathrm{GW}$ ). The basis for the development of the production of "green" hydrogen is to be a well-developed potential of renewable energy production. Based on the SWOT analysis conducted, recommendations and a schedule of actions were formulated, as a result of which the energy use of hydrogen is to significantly contribute to Finland's achievement of carbon neutrality by the 2050. The material prepared by the consulting company Nordic West Office was also devoted to the issue of hydrogenation of the Finnish economy [26].

\section{France}

Work on the use of hydrogen energy begun in France at the end of the last decade of the 20th century. In 1998, public administration units, energy companies, producers of hydrogen and hydrogen installations, electrolysers, motor vehicles, scientific research centres as well as regional authorities established the AFHYPAC association (Association Francaise pour 1 hydrogene et les piles a combustible). In 2013, the H2Mobilite France Consortium, organisation established by the above-mentioned association, developed the first plan for the development of hydrogenation of the French economy limited to the road transport [27]. The ambitious objectives formulated in the Plan, both in terms of the fleet of hydrogen-powered vehicles and the network of hydrogen refuelling stations, have not been achieved to date.

Another, broader-spectrum Program, treating hydrogen technologies as one of the pillars of the planned transformation of the French energy system, was developed in 2018 [28].

Yet another French hydrogen program referred to the findings and even the structure of the content of the quoted report "Hydrogen scaling up. A sustainable pathway for the global Energy transition" prepared in 2017 by the Hydrogen Council.

The findings of the above Program became the basis for the 14-point plan of N. Hulot (the then minister for environmental protection), published on June 1, 2018, to popularize hydrogen as an element of the transformation of the French energy economy [29].

The plan was part of France's second multi-annual energy program covering 2018-2028. As part of the Plan, it was assumed that, starting from 2019, 100 million euro will be spent annually in public funds to support the hydrogenation of the French economy, including for the manufacture of electrolysers producing "green" hydrogen. In September 2020, the national strategy for the development and production of "green" hydrogen was published. 
As part of the above strategy, it was assumed that 7 billion euro will be spent by the 2030, including 2 billion euro of the public funds in 2020-2022 for the development of production and use of "green" hydrogen (for the total amount of planned investments exceeding 32 billion euro). The three main objectives of the strategy are:

- reaching the total capacity of the electrolyser park powered by energy from renewable sources of $6.5 \mathrm{GW}$ by the 2030

- development of hydrogenation of transport, in the first place: trucks, buses and railways, on a scale ensuring a reduction of $\mathrm{CO}_{2}$ emissions by 6 million tonnes by the 2030 (with a reduction of emissions due to the use of "green" hydrogen in all applications of approx. 10 million tonnes)

- development of the research and development facilities and a modern sector of the hydrogen industry employing from 50 to 150 thousand people [30].

\section{Spain}

Spain joined the EU efforts to develop hydrogen technologies practically only in 2020 . By the end of 2019, only 3 hydrogen refuelling stations were in operation, servicing approx. 35 hydrogen vehicles. In Spain, the industry has so far consumed about $0.5 \mathrm{Mt}$ of hydrogen per year, mainly from the steam reforming processes of natural gas.

The basis for accelerating the activities in the field of hydrogen energy use in Spain were: the final version of the "Integrated Energy and Climate Plan" [31] adopted in January 2020 and the "Long-term strategy for the development of a modern, competitive and climate-neutral Spanish economy in the 2050 perspective" published in July 2020 (ELP), which was approved by the Spanish Council of Ministers on November 3, 2020 [32].

The document assumes that the emission of greenhouse gases by the 2050 will be reduced compared to the emissions from 2018 by $90 \%$ (from $334 \mathrm{Mt}$ to $29 \mathrm{Mt}$ ). This will be a consequence of, on the one hand, reduction as a result of increased savings and efficiency of energy use (50\% reduction in final energy consumption by the 2050), and on the other hand, the development of the renewable energy sector (42\% share in final energy consumption in 2030 and $72 \%$ share in electricity production). Based on the above findings, the "Roadmap for the development of the hydrogenation of the economy based on green hydrogen", adopted by the Spanish government on October 6, 2020, was developed [33].

The document contains a plan of 60 different types of actions (regulatory, organizational, financial) to ensure that by the 2030 electrolysers with a total capacity of $4 \mathrm{GW}$ (300-600 MW by 2024) will be installed in the country, 100 hydrogen refuelling stations will be built, which should service 5,000 hydrogen cars, there will be 150 buses and two railways with hydrogen train traffic. In the industry, $25 \%$ of hydrogen consumed in 2030 is to be produced based on electricity from renewable sources. The planned investments (public and private) will cost about 9 billion euro, and their implementation should ensure that as early as 2030 the national $\mathrm{CO}_{2}$ emission will be reduced by 4.6 Mt.

\section{The Netherlands}

The Netherlands has been a European giant in the production of hydrogen for years. Most of the approximately one million tonnes of hydrogen produced primarily from natural gas is consumed by the chemical and refining industries. The issue of using hydrogen for energy purposes, primarily in the road transport, was undertaken in the early years of the 21 st century. The first major transport hydrogenation program was published by the Dutch Ministry of Transport and the Environment in 2013 [34].

Another version of the Dutch transport hydrogenation development plan was presented in the Dutch hydrogen infrastructure development plan (NIP-NL) implemented in 2014/2015 as part of the EU project TEN-T-HIT (Hydrogen Infrastructure for Transport) [35].

The adopted assumptions and goals were verified and expanded in the roadmap for the development of hydrogenation in the Dutch economy, commissioned by the Dutch Ministry of Economy and Economic Policy in 2018 [36].

In the report covering 7 areas of hydrogen use, apart from quantitative projections, the directions of desired activities supporting the development and dissemination of hydrogen technologies by the public administration and other stakeholders as well as the effects in reducing greenhouse gas emissions were defined.

In April 2020, the Dutch government published a national hydrogen strategy based, among the others, on the findings of the above report as well as the findings of the National Climate Agreement, signed in 2019 with social partners [37].

\section{Japan}

Work on the use of hydrogen as an energy source began in Japan in the last years of the 20th century and initially focused on the most emissive area of heating and supplying indoor facilities (40\% of total Japanese $\mathrm{CO}_{2}$ emissions).

In 2002, the first multi-year (2002-2013) research and demonstration program "Japan Hydrogen and Fuel Cell Demonstration Project" was launched. Since 2003, the control of the program has been taken over by a specialized governmental agency "New Energy and Industrial Technology Development Organization" (NEDO).

As part of the program, the first projections of the number of hydrogen refuelling stations and hydrogen vehicles for 2010-2020-2030 were formulated.

In order to accelerate the unsatisfactory development of hydrogen technologies, in 2013 the Council for a Strategy for Hydrogen and Fuel Cell was established. In 2014, a roadmap prepared under the auspices of the Council was published, in which the objectives and schedule for the development of hydrogen technologies in various areas were specified [38].

The directions for the development of the hydrogen economy, updated and supplemented in 2016, became the basis for the official announcement by the Japanese prime minister in April 2017 of the idea of building the world's first "hydrogen society". Following the above declaration, in December 2017, a document specifying the strategy for building a "hydrogen society" was published (Basic Hydrogen Strategy) [39]. 
The development objectives set in the strategy are accompanied by specific recommendations, as well as the financial parametrisation of their economic conditions. Despite the state's involvement (in the years 2013-2018 alone, the Japanese administration supported the research and demonstration projects underway with USD 1.458 billion), the assumed objectives were not fully implemented [40].

The assumptions and objectives for building a "hydrogen society" formulated in the "Basic Hydrogen Strategy" based on the acquired knowledge and practical experience in the implementation of the hydrogen energy use technology have been updated in the next version of the strategic roadmap, published in March 2019 [41].

In the current modification of the assumptions and objectives of the Japanese strategy for building a "hydrogen society" it was emphasized that these goals will be subject to constant evaluation by appropriate expert groups.

Japanese activities in the field of the development of the hydrogen energy use are characterized by systematic and long-term nature and, above all, a comprehensive approach to hydrogen technologies as an instrument for transforming the country's energy system. This does not change the fact that at least the current versions of the development plans in question, in the context of the ambitious goals clashing with reality, are significantly toned down.

\section{Canada}

Work on the hydrogen energy use began in Canada in the 1980s. The research and implementation of the results made Canada one of the world leaders in the development of hydrogen technologies.

The first report on the development of hydrogen transport commissioned by the Canadian Natural Resources Agency was produced as early as 2005 [42]. In the same year, the discussions on the need to develop a strategy for the hydrogenation of the Canadian economy began [43]. The issue of hydrogen-powered vehicles was also mentioned in the directional document "Electric Vehicle Technology Roadmap for Canada"[44] published in 2010. In 2016, the Canadian administration adopted a framework for the development of a zero-emission economy, including the use of hydrogen [45].

The first strictly hydrogen oriented document defining 12 basic directions for the development of the use of hydrogen in the Canadian economy, along with relevant implementation recommendations, was published in 2019 [46]. In June 2020, the governmental agency Natural Resources Canada announced that the work on the preparation of the Canadian hydrogen strategy, which had been postulated for years, had been initiated [47]. The above initiative was supported, among the others, by the Canadian hydrogen association The Canadian Transportation Fuel Cell Association. The date of publishing the strategy has not yet been specified [48].

\section{South Korea}

Research on the hydrogen energy use began in South Korea as part of the 10-year plan - "10 Year Alternative Energy Technology Development Program" in 1988. Work continued under the next edition of the program in 19982007 [49].
The development of hydrogen technologies accelerated after 2000, when the Ministry of Science and Technology (MOST) launched the "High Efficient Hydrogen Program" based on which in 2003 the "21 Century Frontier Hydrogen Production Program" was formulated. At the same time, in 2004, the National DR\&D Organization for Hydrogen and Fuel Cell launched a long-term implementation and demonstration program on hydrogen technologies. A year later, the first directional plan for the development of hydrogenation in the South Korean economy was announced - "Plan for hydrogen economy" [50].

As a result of the combined efforts of the public administration, which supported activities related to the development of hydrogen technologies with an amount of USD 586 million in 2004-2011 alone, and the efforts of the industrial sector in February 2013, the world's first commercial hydrogen FCEV Hyundai ix35 cars rolled off the production lines of the Ulsan factory.

In 2016, the Hydrogen Fusion Alliance associating central and local administration units, automotive companies, energy companies, and research and development centres, published a report on the development of hydrogenation of Korean car transport in 2020-2030 [51].

In order to boost the hydrogenation of the Korean economy, a working group was established in 2018, consisting of representatives of the public administration and the private sector, with the task of developing a road map for the development and dissemination of hydrogen technologies [52].

This document presenting a vision of the development of hydrogen technologies in South Korea by the 2050 was published in early 2019 [53].

\section{Germany}

In Germany, work on the hydrogen energy use was undertaken in the 1990s. This work focused primarily on the use of hydrogen in transport.

The subject theoretical studies were launched i.a. as part of the work that began in 1998 on the development of an energy strategy for transport - "Verkehrswirtschaftliche Energiestrategie" (VES). The implementation of clean energy technologies, including hydrogenation of transport, was undertaken within the framework of the Clean Energy Partnership (CEP), established in 2002 by the interested entities, on the initiative of the Federal Minister of Transport, Environment and Construction (BMVBS). In March 2006, the same Minister announced the first government plan to support the development of hydrogen technologies in 2006-2016, amounting to 500 million euro (which eventually increased to 700 million euro) [54].

The funds were used to finance the implementation of the National Innovation Program Hydrogen and Fuel Cell Technology (NIP I). In order to manage the above program, in 2008 the governmental organization National Organization Hydrogen and Fuel Cell Technology - NOW Gmbh was established. Today, this organization manages the second edition of the program (NIP II) covering the years 2016-2026 (Program for Hydrogen and Fuel Cell Technology 2016-2026 - for market preparation for competitive products). Despite the involvement of significant funds, also from public budgets, the implementation of German 
transport hydrogenation development plans has been marked by significant delays from the very beginning.

The plan from 2008 assumed, inter alia, that in 2015, 100,000 hydrogen cars should be operated in Germany, served by 142-218 hydrogen refuelling stations, and in 2020 respectively 350-580 thousand hydrogen passenger cars and 56-96 thousand hydrogen vans served by 1296-2666 [55] hydrogen refuelling stations. In the next version of the plan in 2020, 150 thousand. hydrogen-powered cars served by 400 hydrogen refuelling stations [56]. In fact, at the end of 2019 , there were 81 hydrogen refuelling stations in Germany serving just 679 hydrogen powered vehicles [57].

Some dynamics of the implementation of the assumed plans was brought about by the establishment in 2009, by the interested entities, primarily automotive and energy ones, with the participation of NOW GmbH, of a publicprivate initiative supporting the development of hydrogenation of the German H2Mobility transport.

The implementation of the German strategy for the hydrogenation of the economy published in June 2020 should bring a fundamental breakthrough [58]. The strategy defines the necessary actions to achieve the German climate objectives. The basic directions of activities are:

- increasing the competitiveness of hydrogen as an energy medium,

- development of the German market for hydrogen technologies (from 55 TWh currently to $90-110$ TWh in the 2030) associated with the development of international cooperation ensuring the necessary import of "green hydrogen",

- development of knowledge and highly qualified labour resources,

- development of raw material use of hydrogen,

- increase in the share of hydrogen in the country's energy balance,

- development of infrastructure for transport and distribution of hydrogen,

- modelling and support of energy transformation processes by the public authorities,

- development of German industry and securing access to the world markets for German companies,

- participation in the creation and cooperation on the global hydrogen market,

- taking advantage of the opportunities arising from global cooperation,

- creating and ensuring a safe infrastructure for the production, transport, storage and use of hydrogen,

- improvement of the environmental protection policy. The strategy, which is to be evaluated every 3 years [58], assumes 38 concrete activities of various nature, covering both the production of hydrogen and various areas of its use, including:

- improving the competitiveness of electricity from renewable sources (including the introduction of payments for $\mathrm{CO}_{2}$ emissions from transport and heating), as well as limiting the taxation of electricity used to produce "green" hydrogen,

- share of public funds in the construction of electrolysers,
- strengthening financial activities under the National Innovation Program for Hydrogen and Fuel Cell Technology with funds from the Energy and Climate Found fund (3.6 billion euro by the 2023),

- financing from the above Fund for the development of production of advanced biofuels based on hydrogen (1.1 billion euro by the 2025) and the development of charging and refuelling infrastructure for alternative fuels (3.4 billion euro),

- changes to the Eurovignette Directive to make road tolls dependent on the level of $\mathrm{CO}_{2}$ emissions.

Similar activities supporting the development of hydrogen use are also planned for aviation and water transport, as well as for other industries such as steel, chemical industry, logistics and heating [58].

For the hydrogenation of industrial production processes leading to the reduction of $\mathrm{CO}_{2}$ emissions, over a billion euro of public funds alone have been allocated for the period 2020-2023.

The implementation of strategy is to be managed by the interministerial Hydrogen Committee composed of the heads of the ministries involved, supported by the National Hydrogen Council consisting of 26 experts [58].

On 3 June 2020, the Committee adopted a "package for the future" with a budget of an additional 7 billion euro for the development of hydrogen technologies in Germany and 2 billion euro for strengthening international cooperation in the hydrogen economy.

\section{Norway}

In Norway, the first organization supporting the development of hydrogen energy use, The Norwegian Hydrogen Forum, was established in 1996. In 2005, the Ministry of Fuel and Energy and Transport and Communications developed one of the world's first national strategies for the development of hydrogenation of the economy [59]. It was part of the measures taken in Norway since 1989 to counteract global warming. The 2005 study planned a reduction of $\mathrm{CO}_{2}$ emissions by $30 \%$ in $2020,40 \%$ in 2030 and $100 \%$ in 2050 in relation to the emissions from 1990 [60]. The planned activities referred primarily to the electrification, including hydrogenation, transport (road and water) which is responsible for $1 / 3$ of total Norwegian greenhouse gas emissions. The work was continued by The Norwegian Hydrogen Council established by the above-mentioned ministries in 2005.

In 2006, the Council published the first hydrogen technology development plan to the 2020 (Action Plan 20072010) [61].

The adopted objectives, as in other countries supporting hydrogenation of the economy, turned out to be too ambitious and were not achieved. The next version of the plan was prepared by the Council for the years 2012-2015. In 2020, another version of the Norwegian hydrogen strategy was published [62]. It was created based on the "Green Transition Package" presented in May 2020 by the Norwegian government with a budget of over NOK 3.5 billion [63].

The 2020 strategy also focused, apart from the production and trade of hydrogen, on the development of its use in transport. The development of hydrogenation in the road 
transport will result from the adoption of strict restrictions assuming that in Norway from the 2025 new passenger cars, delivery vans and city buses must be zero-emission, and from 2030 also distribution transport in the centres of large cities must be zero-emission. From 2030, $75 \%$ of the long-distance buses and $50 \%$ of trucks must be emissionfree [63].

Ultimately, in 2050, all Norwegian transport is to be zero-emission.

\section{New Zealand}

New Zealand is one of the countries that returned to intensive activities in the field of hydrogen technologies after years of stagnation. The first report on the hydrogenation of the New Zealand economy was made in 2007. This year, New Zealand joined the International Partnership on Hydrogen Economy - which it does not currently belong to, and in 2005 it joined the IEA Hydrogen Implementation Agreement [64].

The modern vision of the development of the hydrogenation of the New Zealand economy was published in September 2019 [65]. The work carried out in 2017-2019 as well as the results of various pilot hydrogen projects launched in those years were used to develop the document [66].

The main assumption of the study is the development, based on the existing renewable energy sources, of the production of "green" hydrogen, which will ensure the implementation of the strategic objective of achieving carbon neutrality of the New Zealand economy by the 2050 (as early as in $2035,100 \%$ of the electricity produced in the country is to come from renewable sources - with $85 \%$ currently) [66].

The "green" hydrogen produced is to ensure the decarbonisation of: transport, industrial processes (production of ammonia and steel and low-carbon oil refining) and the heating sector, and become the subject of export $(300,000$ tonnes in 2035).

Specification of the adopted goals for individual periods (until 2020, in 2020-2025, 2025-2030 and in the longer term) is included in the roadmap [66]. By the 2030, a network of approx. 200 hydrogen refuelling stations is planned (there were none by the 2020) on non-urban roads, complementing the network of stations in the large cities, as well as e.g. introduction to operation of hydrogen vessels. In addition to the national road map for the development of hydrogen technologies, a regional roadmap for the development of an integrated infrastructure for production, transmission, storage and use of hydrogen in the Taranaki port area, which is one of New Zealand's hydrogen hubs, has also been published [67].

The publication of the document, as intended, triggered a nationwide discussion in which all citizens and legal entities, until October 25, 2019, could express their opinions on the proposed directions for the development of the hydrogenation of the New Zealand economy. The results of this discussion are to be used in the future development of a national strategy for building a hydrogen economy.

\section{Portugal}

One of the first European countries, nota bene, with relatively limited achievements in the field of research and implementation of hydrogen technologies so far, which developed a national hydrogen strategy, is Portugal. The need to prepare a strategy for the development of the hydrogenation of the economy was mentioned already in 2007 [68]. Ultimately, such a strategy was published by the Portuguese Council of Ministers in May 2020 and adopted after a public debate in August 2020 [69].

The national hydrogen strategy was based on the results of a series of studies on the role and possibilities of the hydrogen energy use [70], as well as on the roadmap to achieve carbon neutrality by the 2050 developed in 2016 [71] and the National Energy and Climate Plan [72]. The main objectives of the Portuguese hydrogen strategy, similarly to the strategies of other countries, are decarbonisation of the economy and transformation of the country's energy system. This is all the more important in Portugal's Conditions because, on the one hand, $100 \%$ of the fossil fuel consumed is imported, and on the other hand, the country's natural and climatic conditions are extremely favourable for the development of cheap green hydrogen production based on electricity from renewable sources. The Strategy assumes that by the 2030, a share of renewable energy in the national balance will increase to $47 \%$ (also in the electricity production to $80 \%$ ), and the total capacity of electrolysers to $1 \mathrm{GW}$. There should be 50 to 100 hydrogen refuelling stations in the country, which should service from 400 to 750 buses, 400-500 heavy-duty hydrogen-powered cars and 750-1000 hydrogen-powered vans.

Expenditures related to the hydrogenation of the economy in the perspective of 2030 alone were estimated at 7 billion euro, of which about a billion would constitute public funds.

\section{Sweden}

Work on the hydrogen energy use was started by the Swedish concern ASEA (nowadays ABB) in the 60s of the last century. The first systematic research program, Fuel Cell, financed by the Swedish Foundation for Strategies Environmental Research, was launched in 1997. As part of the program lasting until 2010, as well as subsequent initiatives, including EU initiatives, a number of research and demonstration projects devoted to the hydrogen energy use, both nationally and regionally, were carried out.

The most important examples are:

- National Hydrogen Infrastructure Development Plan for Transport [73]

- Swedish transport hydrogenation development program [74]

- or variant scenarios for the assumed development of hydrogenation in the Swedish economy [75].

The starting point for these projects are the arrangements adopted in successive versions of the Swedish energy and climate plans (NECP). Already in 2009, as part of the integrated energy and climate policy, it was assumed that by the 2050 Sweden would become an emission-neutral country (in the current version even in 2045), and an important step in this regard should be the complete independ- 
ence of the Swedish transport by the 2030 from oil-derived fuels.

This does not change the fact that the long-term national strategy for the hydrogenation of the Swedish economy, including Swedish transport, has not yet been specified.

\section{United Kingdom}

The real interest in hydrogen as an energy carrier in Great Britain appeared only in the 2000s. This interest was initially focused on the use of hydrogen in the road transport, and then also in heating and powering buildings.

In 2013, The UK H2 Mobility, an organization created in 2011 by the government administration and automotive and energy entities, published the first directional plan for the implementation of hydrogen propulsion in British transport in 2015-2030 [76].

The first comprehensive vision of the potential benefits of the development of hydrogenation in the British economy was presented in a report commissioned by the government administration by the consortium: E4 Tech and Element Energy and published at the end of 2016 [77]. Already this report underlined the need for a British hydrogen strategy [77].

This does not change the fact that despite a number of achievements in the hydrogen technology and the involvement of many British players, this strategy has not been developed to date.

Postulates regarding the necessity to develop a national hydrogen strategy have intensified especially in the last several months. There were, among the others, in a report published in 2020, which presents the next version of the hydrogen road map until 2035 (with a perspective until 2050) [78]. The Business Energy and Industrial Strategy Committee also called for an urgent development of a national hydrogen strategy [79]. In the report "Renewable Hydrogen - Seizing the UK Opportunity", the implementation of the above-mentioned postulate was specified at the end of 2020 [80]. So far, a half-answer has been brought by the 10-point green plan announced by the British Prime Minister on November 17, 2020 [81]. Although the above plan includes hydrogen technologies among other technologies leading to the reduction of greenhouse gas emissions by 2035 , but it differs significantly from the programming documents on hydrogenation prepared in other countries.

\section{Italy}

Work on the hydrogen energy use began in Italy in the early 2000s. In 2005, the first Italian hydrogen platform was launched under the auspices of the Ministry of the Environment. In 2016, the Mobilite H2IT Hydrogen Association (Associazione Italiana Idrogeno e Cella Combustile - Mobilita Idrogena H2IT) prepared, for the needs of the Italian Ministry of Development, the first version of the "National Development Plan for Hydrogenation in Car Transport". The provisions of the above plan were incorporated into the Italian "Alternative Fuels Infrastructure Development Plan". A modified version of the "National Road Transport Hydrogenation Development Plan" was released in 2019 [83].

In November 2020, a draft of initial guidelines for the preparation of the Italian economy hydrogenation strategy was published. The document assumes that by the 203010 billion euro will be invested in the hydrogenation of the Italian economy, $50 \%$ of which will be from public funds, and these investments will reduce Italian $\mathrm{CO}_{2}$ emissions by $8 \mathrm{Mt}$, provide 200,000 new jobs and an increase in Italian GDP by 27 billion euro a year.

\section{USA}

The United States of America are a country that started the era of practical hydrogen energy use in the seventies of the last century, incl. in the Gemini and Apollo space programs.

In the Energy Act of 1992, hydrogen was already mentioned among domestic energy sources [84]. In the national energy policy of 2001, it was recommended to start work on technologies for the hydrogen energy use in various applications [85].

In February 2002, the US Ministry of Energy published precursor, on a world-scale, vision of the hydrogen economy development [86]. The first national roadmap for the development of economic hydrogenation, published in November 2002, brought the vision into reality [87]. The above studies were not implementation documents, but only information and cognitive ones. In the next EPAC energy law in 2005, an entire chapter was devoted to the hydrogen [88]. Following the provisions of EPAC from 2005, the Ministry of Energy in 2006 published an integrated plan of research and development works and demonstration activities in the field of hydrogen economy [89]. Another version of the plan was published in 2011 [90]. In 2017, a multivariant scenario for the hydrogenation of American road transport was published [91]. In June 2020, the Ministry of Energy published the preliminary assumptions of the hydrogen strategy, recognizing hydrogen as one of the basic elements of building a low-carbon economy [92]. The document summarizing the development of hydrogen technologies to date defines four priority directions, namely the development of "green hydrogen" production, the development of hydrogen infrastructure supporting transport, the development of hydrogen storage capacity and the development of the use of hydrogen for energy and fuel production.

In total, in the years 2004-2018, the Ministry of Energy and its subordinate institutions spent over USD 2.1 billion in public funds to support research and development activities [93].

Despite the American achievements, primarily in science, and support for the development of hydrogen technologies by the public administration, this country being one of the leading hydrogen countries, has not yet developed and adopted a national strategy for the hydrogenation of the economy [94].

The need for such a document specifying and coordinating both the current and future directions of activities is postulated by a number of projects implemented in various areas of hydrogenation development, especially transport [95]. The scientific response to the above demands was the preparation in 2020, under the auspices of Fuel Cell and Hydrogen Energy Association, of the American roadmap for the hydrogenation of the economy. According to the study, in 2030, hydrogen should account for $14 \%$ of all 
energy consumed in the US, which should result in a $16 \%$ reduction in $\mathrm{CO}_{2}$ emissions and a $36 \%$ reduction in $\mathrm{NO}_{\mathrm{x}}$ emissions. The turnover of the sector with 3.4 million employees should reach USD 750 billion [96].

\section{Discussion}

The proper policy framework has a major impact on the development of new technologies, in particular in the research, prototype deployment and pre-dissemination phases. This fully applies to the technology of using hydrogen energy.

The survey shows that by the end of 2020, various types of documents have been developed in over 20 countries: plans, programs, road maps, national strategies for the development of hydrogen technologies. The main common points of these studies include:

- recognition of hydrogen as an important component of the transformation of national energy systems towards reducing the generated $\mathrm{CO}_{2}$ emissions

- persistent uncertainty as to the dynamics of the decline in costs of production of hydrogen and other elements of hydrogen technologies

- focus on the energy use of hydrogen

- emergence of a group of countries with favourable conditions for cheap production of green hydrogen based on renewable energy sources.

Counteracting further global warming has become not only an absolute priority for the European Union, but also hydrogen has been widely recognised as one of the key factors in the necessary transformation. The production costs of individual components of hydrogen technologies' energy systems entered the path of their radical reduction (e.g. the costs of producing "green hydrogen" in Chile in the process of water electrolysis based on electricity from renewable sources fell to the level of 0.8-1.0 US dollars per kilogram of hydrogen). The continuous improvement of hydrogen technologies, including a significant improvement in their energy efficiency, was also of great importance. The coming years will show which direction the world energy transformation will take, but there is no doubt that the energy use of hydrogen in transport will certainly be an important element of it.

It seems that we are currently at a turning point in the development of hydrogen propulsion technology. The expansion of the network of hydrogen refuelling stations and the gradual development of the hydrogen vehicle park, undertaken primarily by public administration, also under many international programs, may break the existing development deadlock. This impasse should be overcome by the observed and expected steady decline in the costs of, first of all, the construction of hydrogen refuelling stations, which have already fallen from 1.5 million to approx. 700-800 thousand Euro at present and the production costs of hydrogen vehicles. The construction costs of a hydrogen refuelling station should drop to PLN 390-470 thousand Euro in 2030 yet. The production costs of a hydrogen passenger car should decrease from 62 thousand, in 2015 to 22.6 thousand Euro in 2030, 18.7 thousand Euro in 2040 and 18 thousand Euro in 2050. Hydrogen unit prices and the annual maintenance costs of a hydrogen vehicle should also fall.
The energy use of hydrogen in recent years in many economic sectors, among the others in transport, including especially motor transport, has finally reached the precommercial phase. In practice, this means that the technologies developed, e.g. hydrogen propulsion of transport means (except aviation), could already become an increasingly important element of the necessary transformation of the global energy economy towards its gradual decarbonisation.

Not only the individual countries have developed their national strategies for the development of hydrogenation, but this topic has also been taken up by the European Union. On July 8, 2020, the European Commission published the "Strategy for the development of hydrogenation of the economy as an element of building Europe's climate neutrality".

The basic premise of the EU's hydrogen strategy is the development and production of green hydrogen, i.e. the hydrogen produced with electrolysers powered by electricity from renewable sources. Although green hydrogen currently accounts for only $4 \%$ of the 8 million tons of hydrogen consumed in Europe, in the future it is to play an increasingly important role both as an integrator of individual economic sectors and as an energy carrier enabling the decarbonisation of economic processes that are difficult or impossible to electrify directly. The share of green hydrogen in the European energy mix is expected to increase from the current $2 \%$ to $13-14 \%$ in 2050.

The European Commission has unequivocally confirmed that the development of the economy hydrogenation is one of the key elements in achieving the goal of reducing the EU $\mathrm{CO}_{2}$ emissions by $50-55 \%$ yet in 2030 . To this end, in the years 2021-2024, new electrolysers with a total capacity of at least $6 \mathrm{GW}$, are yet to be built, that are expected to produce $1 \mathrm{Mt}$ of green hydrogen per year.

In the published strategy, one of the priority lines of action remains the hydrogenation of transport: from the hydrogenation of buses serving local lines, through the hydrogenation of heavy long-distance road transport, rail transport operating on lines used on a scale that does not justify their electrification, the hydrogenation of inland and coastal shipping, to the hydrogenation, on the long run, of aviation and ocean shipping.

In order to implement the planned strategy along with its publication, the European Commission established an organisation called (European Clean Hydrogen Alliance). This alliance brings together representatives of industry, civil society, various levels of government and the European Investment Bank.

The publication of the strategy and the establishment of the said alliance clearly confirmed the important role of hydrogen in the transformation of the EU energy system towards its carbon neutrality, in the recovery of the economy after the collapse caused by the Covid-19 pandemic, and in building a strong, competitive position of the EU on the emerging global hydrogen market.

\section{Conclusions}

Only in the years 2018-2019, public authorities in 21 countries pursued a policy of direct support for the research and development of hydrogen energy technologies. These 
activities were carried out under approximately 50 different initiatives (most in the transport sector: 15 for hydrogenpowered passenger cars and 10 for buses and hydrogen refuelling stations) [97].

Government spending on the research and development alone in the field of hydrogen energy technology in 20152018 exceeded US \$ 11 billion worldwide and is constantly growing [97].

An effective use of the incurred expenditures undoubtedly requires the interested states to formulate an appropri- ate policy (strategy) for the hydrogenation of the economy, including, in addition to precisely defined long-term objectives, e.g. elements of support from public administration, assurance of: stable investment conditions and the necessary regulatory conditions.

In the coming months, the publication of new or updated versions of these documents is expected in other countries such as: Austria, Denmark, Italy, Great Britain, Canada, Poland, Colombia, Paraguay, Uruguay, Morocco.

\section{Bibliography}

[1] BEZDEK, H.R. The hydrogen economy and jobs of the future. Renewable Energy and Environmental Sustainability. 2019, 4. https://doi.org/10.1051/rees/2018005

[2] HYDROGEN SCALING UP. A sustainable pathway for the global energy transition. Hydrogen Council. 2017.

[3] SAMSUN, R.C., ANTONI, L., REX, M. Mobile fuel cell application: tracking markets trends. IEA Technology Collaboration Programme Advanced Cell. 2020.

[4] Towards development of an Australian scientific roadmap for hydrogen economy. Australian Academy of Science. Canberra 2008.

[5] Opportunities for Australia from hydrogen export. ACIL Allen Consulting. 2018.

https://www.arena.gov.au/assets/201808/Opportunities-forAustralia-from-hydrogen-eksport

[6] FLOYD, H., HIBBERT, A., AMICO, A. Hydrogen for transport. Perspective Australian use case. Aurecon. Melbourne 2019.

[7] Australia's National hydrogen strategy, Council of Australian Government. Energy Council Hydrogen Working Group, Department of Industry, Innovation and Science. Commonwealth of Australia 2019.

[8] South Australia's hydrogen action plan. Government of South Australia. 2019.

https://www.renewablessa-

sa.gov/en/content/uploads/2019/09/south-australiahydrogen-action-plan

[9] Queensland hydrogen industry strategy. Queensland Government. May 2019.

https://www.dsdmip.gld.gov.au/resources/strategy.queenslan d-hydrogen-industry-strategy.pdf

[10] Estrategia Nacional de Hidrogene Verde Chile, fuenta energetica para un planeta zero emisiones. Ministerio de Energia. Gobiermo de Chile, Santiago de Chile 2020.

[11] GORIP, P. Chile spearheads green hydrogen strategy. Argus Media. 20 October 2020.

http://www, argusmedia.com/en/news/2150326-chilespearheads-green-hydrogen-strategy

[12] LUN, J. Hydrogen fuel cell vehicles development in China. Pekin 2016

https://www.un.org/esa/sustdev/csd/csd14/lc/presentation/hy drogen4.pdf

[13] National key R\&D programmes.

http://www.chinainnovationfounding.eu/national-key-rdprogrammes

[14] VERHEUL, B. Overview of hydrogen and fuel cell development in China. Holland innovation network in China. Pekin 2019.

[15] Made in China 2025: Mercator Institute for China Studies, 12 August 2016.

http://www.mercis.org/en/report/made-in-china-2025

[16] Hydrogen fuel cell vehicle technology roadmap: strategy advisory committee of the technology roadmap for energy

saving and new energy vehicles. Society of Automotive Engineering of China 2016.

[17] China's energy innovation action plan 2016-2030. China Energy Storage Alliance. Pekin 2016.

https://www.en.cnsesa.org/featured-stories/2016/5/8/chinasenergy-innovation-action-plan

[18] Hydrogen power: China backs fuel cell technology, Financial Times (accessed on 2.01.2019)

https://www.ft.com/../27cefc90-fa-49-11-e81of462022a06.02.a6e

[19] JIANJUN TU, K. Prospects of a hydrogen economy with Chinese characteristics. Etudes de l'IFRI (The Institute francaise des relations internationale). Paris 2020.

[20] White paper on China hydrogen and fuel cell industry. China Hydrogen Alliance (H2CN). June 2019.

[21] The Danish hydrogen energy programme.

[22] National research \& development and demonstration strategy for FCH transport.

[23] National implementation plan for hydrogen refuelling infrastructure in Denmark. Fuel cells programme, toward demonstration and public awarance, Tekes, Politokennot, Helsinki, 2007.

https://www.eurosfires.prd.fr/7pc/documents/137414705/_oj apale fchju maritime 20130 14062013 public.pdf

[24] The Finnish hydrogen roadmap: Hydrogen to join electricity in the ending traffic pollution. VTT Research Centre of Finland.

https://www.newcision.com/VTT-info/r/the-finishhydrogen-roadmap-hydrogen-to-join-electricity-in-theending-traffic-pollution-c9419673

[25] LAURICO, J. Hydrogen roadmap of Finland. VTT June 2020.

https://www.businessfinland.fi/4a828e/globalassets/finishcustomers/02-bulid-your-network-bioeconomycleantech/alyhas-energia/hydrogen-roadmap-forFinland2020-10-06-final-pdf-002.pdf

[26] Finland and the hydrogen economy. Nordic West Office. Helsinki 2020.

[27] H2Mobilite France: study for a fuel cell electric vehicle. National Development Plan. Mobilite Hydrogene. France 2014.

[28] Developpment 1 Hydrogene pour 1 econmie francaise, Etude prospective, Association francaise 1 hydrogene et les piles combustible. Paris 2018.

[29] Plan de deployement de 1 hydrogene pour la transition energetique, Rapport de Ministere de la Transition Ecologique et Solidaire. Paris 2018.

[30] Strategie national pour le developpment de 1 hydrogene decarbone en France, Ministere de la Transition Ecologique, Ministere de 1 Economie, les Finances et de la Relance, Ministere de 1 Enseigmenent Superieur, de la Recherche et de 1 Innovation, Secretariat general pour 1 investissment, Paris. September 2020. 
[31] Plan Nacional Integrado de energia y clima 2021-2030, Ministerio para la Transicion Ecologica y el Reto Demografico (MITECO). Madrid 2020.

https://www.ec.europa.eu/energy/sites/ener/files/documents/ es/_final_necp_main_en.pdf

[32] Estrategia de decarbonization a largo plazo para una economia espanola moderna, competitiva y climaticamento neutra en 2050. Mondoa. Madrid 2020,

https://www.lamondoba.gob.es/consejodemi/Paginas/enlace s/03.11.2020-enlaces-clipa-aspx

[33] Hoja de ruta del Hidrogeno: una apuesta por el hidrogeno renovable, Ministerio para la Transmision Ecologica y el Reto Demografico (MITECO). Madrid 2020.

https://www.miteco.gob.es/es/prensa/ultimas-politicaselgobierno-aprueba-la-hoja-de-ruta-del-hidrogeno-unaapuesta-por-el-hidrogeno-renovable

[34] On the way to sustainable mobility. Make room for hydrogen powered vehicles. Dutch Ministry of Infrastructure and Environment.

[35] WEEDA, M. NIP-NL, Energy research centre. (and) WEEDA, M. Economical analysis of HRS build-up in the Netherlands. Energy Research Centre. Petten 2015.

[36] GIGLER, J., WEEDA, M. Outlines of a hydrogen roadmap. TKI Nieuw Gas Top Sector Energie. TKI Energie and Industry 2018.

[37] Government strategy on hydrogen. 2020. https://www.govermental.nl.2020/04/04

[38] The strategic roadmap for hydrogen and fuel cells. Agency for Natural Resources and Energy 2014.

[39] Basic hydrogen strategy. Ministerial Council on Renewable Energy, Hydrogen and Related issues 2017.

[40] NAGASHIMA, M. Japan's hydrogen strategy and its economic and geopolitical implications. The Institute Francaise des Relation Internationale 2018.

[41] Formulation of a new strategic roadmap of hydrogen and fuel cells. Ministry of Economy, Trade and Industry. Agency for Natural Resources and Energy 2019. http://www.meti.gov.jp/english/press/2019/03/12/12.002.html

[42] Transforming the future: moving towards fuel cell power fleets in Canada urban transport system. Report for Natural Resources Canada done by Marcon DDH HIT, Montreal 2005.

[43] Towards a national hydrogen and fuel cell strategy a discussion document for Canada. Government of Canada 2005 and Canada needs a national hydrogen and fuel cell strategy. https://www.chcfa.ca/resources/chfca-blog/canada-needs-anational-hydrogen-and-fuel-cell-strategy

[44] Electric Vehicle Technology Roadmap for Canada, electric mobility Canada. Government of Canada 2010.

[45] Pan-Canadian framework on clean growth and climate change: Canada's plan to address Climate Change Canada 2016.

https://www.publications.gc.ca/collections_2017/eccce/En4294-2016-eng.pdf

[46] 2019 Hydrogen pathways - enabling a clean growth future for Canadians. Government of Canada.

https://www.hrcan.gc/ca/energy-efficiencytransportation/resources-library/2019-hydrogen-pathwaysenabling-a-clean-growth-future-for-canadians/21961

[47] MOORE, A. Canada confirms it is developing national hydrogen strategy. S\&P Global Platts. 9 June 2020. https://www.spglobal.com/platts/en/,mrket-insights/latestnews/metals/060820-canada-confirms-it-is-deveopingnational-hydrogen-strategy

[48] CHFCA support for the release of national hydrogen strategy. https://www.chfca.ca/wp-

content/uploads/2020/10/CHFCA/Support-for-H2-Strategy22oct2020-final.pdf

[49] LAURIKO, J. Transport related hydrogen activities in Asia. VTT. February 2006.

[50] LEE, C.M. Hydrogen and fuel cell activity in Korea. IPHE. September 2005.

[51] MEILLAUD, L. Korea strongly promotes the fuel cell cars. https://www.hydrogentoday.info, 26 August 2016.

[52] SHIN, JI-HYE. Korea takes steps towards hydrogen economy. The Korea Herald. 12 September 2018.

[53] Hydrogen economy roadmap of Korea. Ministry of Trade. Industry and Energy. Seul 2019.

[54] The German Wasserstoffspiegel, 2006, 2. https://www.dwrinfo.de/acktuelles/haupt_wspiegel.htm

[55] JOEST, S., FICHTER, M., BUNGER, U. et al. Studie zur Frage, woher kommt der Wasserstoft in Deutschalnd bis 2050. Final report of project Germany Hy, August 2008.

[56] LEMKE, R. Market introduction of hydrogen fuel. Genehmitage Dissertation. Berlin 2016.

[57] SAMSUN, R.C., ANTONI, L., REX, M. Mobile fuel cell application: trucking market trends. IEA Technology Collaboration Programme Advanced Fuel Cell. March 2020.

[58] The national hydrogen strategy. Federal Ministry for Economic Affairs and Energy. Berlin 2020.

[59] National hydrogen strategy. Norwegian Government. Ministry of Energy and Environment and Ministry for Transport. Oslo 2005.

[60] The Norwegian hydrogen guide. Norwegian hydrogen forum. https://www.view.hydrogen.no

[61] Fuel cells and hydrogen in Norway. FuelCellToday.

[62] The Norwegian Governments hydrogen strategy towards a low emission society. Norwegian Ministry of Petroleum and Energy. Norwegian Ministry of Climate and Environment. Oslo 2020.

[63] Norway to launch hydrogen strategy. Energy Global. 10 June 2020.

https://www.energyglobal.com/otherrenewables/10062020/norway-tolaunch-hydrogenstrategy/

[64] CLEMES, T., GARROD, M., LEVI, T. Transitioning to a hydrogen economy: issue document. CRL Energy Ltd. Lower Hutt. New Zealand 2007.

[65] A vision for hydrogen in New Zealand. Ministry of Business. Innovation and Employment. Wellington 2019.

[66] Hydrogen in New Zealand. Report 1 - Summary. Concept Consulting Group Ltd 2019.

[67] H2 Taranaki roadmap. How hydrogen will play a key role in our new energy future. Tapua Rora. New Plymouth 2019.

[68] MURRAY, M.L., SEYMOUR, E.M., PIMENTA, R. Towards a hydrogen economy in Portugal. International Journal of Hydrogen Energy. 2007, 32(15), 3223-3229.

https://doi.org/10.1016/j.ijhydene.2007.02.027

[69] EN-H2 estrategia nacional Para Hidrogenio Portugues, Ambiente Acao Climatico, May 2020.

[70] Integracjo Hidrogienio mas Cadeas de Walor - Sistemas energeticos integrados mais limpos e inteligentes, Direcao Geral de Energia e Geologii, Lisbona 2018.

[71] Roadmap for carbon neutrality 2050 (RNC 2050 Long term strategy for strategy of the Portugalless economy 2050). https://www.unfccc.int/sites/defaults/files/resources/RNC20 50_EN-PT20\%Long\%20Term\%20Strategy.pdf

[72] Integrated National Energy and Climate Plan 2021-2030, December 2018.

https://www.ec.europa.eu/energy/sites/ener/files/documents/ ec_courtesy_translation_pt_necp.pdf 
[73] EU Trans European Transport network (TEN-T) hydrogen Infrastructure for Transport Project HIT, EU 2014 and HIT2-Corridors. EU 2015.

[74] WALMARK, G. The Swedish hydrogen report. SWECO, HFC Nordic 2016.

[75] Sweden - opportunities for hydrogen energy technologies considering. The National Energy and Climate Plans (NECP). Fuel Cell \& Hydrogen 2 Join Undertaking 2020.

[76] UK H2 Mobility, Phase1 results, April 2013.

[77] HART, D., HOWES, J., MADDEN, B. et al. Hydrogen and fuel cells opportunities for growth a roadmap for the UK. E4tech. Element Energy. London 2016.

[78] Establishing a hydrogen economy. The Future of Energy 2035, ARUP, 2020.

[79] COMAN, Y. Can a hydrogen boom fuel a green recovery for Britain? The Guardian, 20 July 2020.

[80] Renewable hydrogen - seizing the UK opportunity, renewable UK, September 2020.

https://cdn.ymaws.com/www.renewableuk/resource/resmgr/ renewable_hydrogen_seizing.pdf.

[81] PM outlines his Ten Point Plan for green industry revolution for 250.000 jobs. Prime minister office, 10 Downing Street. 18 November 2020.

[82] Piano Nazionale di Sviluppo Mobilita Idrogene, Italy, October 2019.

https:/www.h2it/wp-content/uploads/2019/12/Piano_ Nazionale_Monilita_Idrogene_Integrale_2019_Finale.pdf

[83] Strategia Nazionale Idrogeno, Linee Guida Preliminaria, Ministerio dello Sviluppo Economico, 2020.

https://www.mise.gov.it/images/stories/documenti/Strategia _Nazionale_Idrogeno_Linee_Guida_preliminari_nov20.pdf

[84] The Energy Policy Act of 1992, Public law 102-486-24, October 1992.

https://www.ofdc.energy.gov/files/pdfs2527.pdf

[85] Energy innovation in the United States. Automotive Fuel Cell Applications. OECD. https://www.oecede.org/science/inno/31968387.pdf

[86] A national Vision of America's transition to a hydrogen economy to 2030 and beyond. US Department of Energy. February 2002. https://www.cere.energy.gov/hydrogenandfuelcells/visiondoc.pdf

[87] National Hydrogen Energy roadmap. US Department of Energy. November 2002.

https://www.cere.energy.gov/hydrogenandfuelcells/nationalh2-roadmap.pdf

[88] Energy policy Act of 2005. Public Law 109-58-8 August 2005.

https://www.congress.gov/109/plaws/pub1/58/PLAW109publ/58.pdf

[89] Hydrogen Posture Plan. An integrated Research Development and Demonstration Plan. US Department of Energy. US Department of Transportation. Washington 2006.

[90] Hydrogen and Fuel Cells Program Plan. An Integrated Strategic Plan for the Research Development and Demonstration for Hydrogen and Fuel Cells Technologies. US Department of Energy. Washington 2011.

https://www.hydrogen.energy.gov.pdfs/programplan2011.pdf

[91] MELAINA, M., BUSH, B., MURATORI, M. et al. National Hydrogen Scenarios. H2 US Location Roadmap Working Group. National Renewable Energy Laboratory 2017.

[92] Hydrogen strategy: Enabling a Low Carbon Economy. US Department of Energy. Washington 2020.

[93] Hydrogen Programm. https://www.hydrogen.energy.gov/budget.html

[94] MOORE, A. Feature: Canada developing national hydrogen strategy: US taking different approach. S\&P Global Platts. 9.06.2020.

[95] MELAINA, M., BUSH, B., MURATORI, M. et al. National Hydrogen Scenarios, How many stations, where and when? H2 US Location Roadmap Working Group. National Renewable Energy Laboratory 2017.

[96] Road Map to US Hydrogen economy. Reduction emissions and driving growth across the nation.

[97] The Future of Hydrogen. Seizing today's opportunities. Report International Energy Agency for meeting of G20 in Osaka 2019.

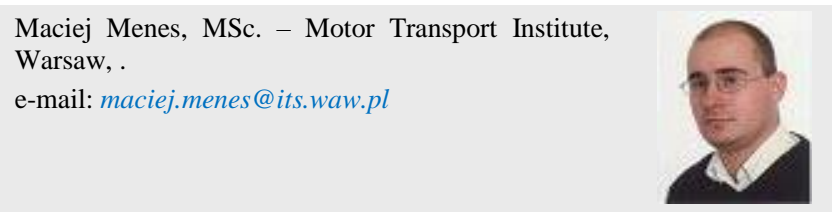

